\title{
Role of social media in reference to North-East ethnic violence
} (2012)

\author{
Juhi P. Pathak \\ Junior Research Fellow (UGC), Department of Communication and Journalism, Gauhati University, Assam, \\ India
}

\begin{abstract}
Social media, in simple words, means text, words, pictures, video and the like created with the intention of sharing. The act of sharing is often for the purpose of making a better or more informed choice. Social media has a remarkable democratizing effect. Tools like blogs, photo and video sharing inspire and allow us to share our thoughts and contents in ways that we never thought of before. The low cost of social media tools, their user-friendliness and the overwhelming presence of internet have all culminated and resulted in the perfect brew for sharing contents and ideas, create cost effective strategies and campaigns that can have viral effect, power to drive in traffic to publicize content, bind people together to meet at a single point and provide a platform for expressing views. But all the benefits and advantages of social media gets marred and eclipsed when some miscreants use the medium for anti-social propaganda with a view to create upheaval and chaos in the society. The researcher, in this paper, will be dealing with the case of the ethnic violence in Northeastern region of India that was triggered in the year 2012 due to the unethical use of social media. Aggravation of the communal situation through the negative use of social media is a new challenge that the recent disturbances have thrown before us. The researcher focuses on the need to devise strategies to counter the propaganda that is carried out by these new means. Any measure to control the use of such media must be carefully weighed against the need for the freedom to express and communicate.
\end{abstract}

Keywords: Media, North-east, ethnic violence, social media, cyber crime

\section{OBJECTIVES}

1. To trace the history of social media.

2. To take an overview of the advantages and disadvantages of social media.

3. Critically analyze the role of social media in the North-east ethnic violence in 2012.

4. Suggest ways to stop the incitement of ethnic violence through social media.

\section{RESEARCH QUESTION}

Can social media actually incite ethnic violence or there are other factors acting as catalyst?

\section{RESEARCH DESIGN}

The research is a Historical, Descriptive and Diagnostic one. The researcher has taken the case study of 2012 incident of ethnic violence that was triggered by the misuse of the social media. Moreover it will be an exploratory study as not much literature was available on the topic and the study is this field is a new one so we have to explore the possible ways of curbing the misuse of social media. The data are mainly collected through secondary sources like books, newspapers, magazines and internet sources and primary sources like interviews.

\section{Introduction To Social Media}

Wikipedia, in 2006, defined social media as 'Social Media is the democratization of information, transforming people from content readers into publishers. It is a shift from a broadcast mechanism, one-tomany, to a many-to-many model, rooted in conversations between authors, people and peers. (Frakes, 2010)

Wikipedia, in 2010, expanded the definition a bit, 'Social media is a media designed to be disseminated through social interaction, created using highly accessible and scalable publishing techniques. Social media uses Internet and web-based technologies to transform broadcast media monologues (one to many) into social media dialogues (many to many). It supports the democratization of knowledge and information, transforming people from content consumers into content producers. (Frakes, 2010)

In 2014, Wikipedia defines the term as 'Social media is the interaction among people in which they create, share or exchange information and ideas in virtual communities and networks. Andreas Kaplan and Michael Haenlein define social media as "a group of Internet-based applications that build on the ideological and technological foundations of Web 2.0, and that allow the creation and exchange of user-generated content." 
Furthermore, social media depend on mobile and web-based technologies to create highly interactive platforms through which individuals and communities share, co-create, discuss, and modify user-generated content. They introduce substantial and pervasive changes to communication between organizations, communities, and individuals.' (Source: Wikipedia)

Social media differ from traditional or industrial media in many ways, including quality, reach, frequency, usability, immediacy, and permanence.

\section{COMPONENTS OF SOCIAL MEDIA}

Frakes (2010) mentions that social media can be said to have three components:

I. $\quad$ Concept (art, information, or meme);

II. Media (physical, electronic, or verbal);

III. Social interface (intimate, direct, community engagement, social viral, electronic broadcast or syndication, or other physical media such as print).

\section{THE RISE OF THE SOCIAL NETWORK}

Blogs emerged out of the online diaries of the mid 1990s. In 1999, the first commercial blogging services - Blogger and LiveJournal - were launched. Blogs started making serious inroads in 2002 and rapidly rose in popularity over the next few years.

At the heart of the blog explosion was the convergence of a number of technical phenomena. Simplified web publishing tools were a real trigger. Writing a blog became as easy as composing and sending an email message. Similarly, mass adoption of affordable broadband Internet access at home made creating and managing websites easier than ever. At the same time, consumer electronics including PCs and laptops, fell in price making computing so easy.

While technology may have sparked the blog revolution, technology has never been the driving force behind online social interaction. From BBSs to chat rooms, forums, and blogs, human nature is at the heart of creating and building online communities. From the very beginning of computer networking, the Web has been a place for social interaction. That's why we call it social media.

Blogs, social networks like Facebook, and microblogging platforms like Twitter are simply technologies that foster communication, sharing and collaboration. These social media tools fit into a bucket of technologies sometimes called Web 2.0, a term we often come across.

Although online interaction is nothing new, these highly networked technologies make massive, global online communication accessible to anyone with an internet connection. Even more profound, they add a participatory element to online communication. Blogs and social networks invite participation. With a click of a button they turn audiences into creators and strangers into friends. (Barefoot \& Szabo, 2010)

\section{CLASSIFICATION OF SOCIAL MEDIA}

Social media technologies take on many different forms including magazines, Internet forums, weblogs, social blogs, microblogging, wikis, social networks, podcasts, photographs or pictures, video, rating and social bookmarking. Technologies include blogging, picture-sharing, vlogs, wall-posting, music-sharing, crowdsourcing and voice over IP, to name a few. Social network aggregation can integrate many of the platforms in use.

By applying a set of theories in the field of media research (social presence, media richness) and social processes (self-presentation, self-disclosure), Kaplan and Haenlein created a classification scheme in their Business Horizons (2010) article, with seven different types of social media:

1. collaborative projects (for example, Wikipedia)

2. blogs and microblogs (for example, Twitter)

3. Social news networking sites (for example, Digg and Leakernet)

4. content communities (for example, YouTube and DailyMotion)

5. $\quad$ social networking sites (for example, Facebook)

6. virtual game-worlds (e.g., World of Warcraft)

7. $\quad$ virtual social worlds (e.g. Second Life)

However, the boundaries between the different types have become increasingly blurred.

\section{DISADVANTAGES OF SOCIAL MEDIA}

The wrong online brand strategy could put you at a viral social disadvantage and may even damage your reputation, i.e, when you make a mistake offline, a few will know but when you make a mistake in front of hundreds or thousands of you online audience, most of them will know!

Using social media for marketing and advertising could be more time consuming than companies expect. 
In order to get social media's full effect, you need to understand how it works, when and how to use it and which channels to focus on depending on your end goal of using social media.

Social media can have a negative influence on worker productivity. Employees may waste valuable time using social media channels such as Facebook and Twitter. They can also use social media to attack the company's reputation!

When social media is used excessively or in the wrong way, it could have serious detrimental outcomes on both mental and even physical health of individuals. (Source: http://blog.thoughtpick.com/)

\section{ADVANTAGES OF SOCIAL MEDIA}

When using social media for marketing products, social media could be easily utilized to create cost effective strategies and campaigns that can create viral results.

Social media has the power to drive traffic to your website, blog, articles, etc.

Social media is able to bring people together, especially when promoting global products or causerelated campaigns and ideas since it allows people from the different geographical location to meet at a single point and express their views.

Social media could be the spark you are looking for to attract attention to your site, product or service. It could also be used to further build loyalty and long-term relations with your audience.

Social media marketing could always be a fun and creative method of doing business. (Source: http://blog.thoughtpick.com/)

\section{The 2012 North-East Violence}

When using social media for marketing products, social media could be easily utilized to create cost effective strategies and campaigns that can create viral results.

In July 2012, violence in the Indian state of Assam broke out with riots between indigenous Bodos and Bengali-speaking Muslims. The first incident was reported to have taken place on 20 July 2012. As of 8 August 2012, 77 people had died and over 400,000 people were taking shelter in 270 relief camps, after being displaced from almost 400 villages.

The violence and exodus of thousands of people from Northeast India reportedly led to a series of incessant protests in Assam, at multiple locations, during the months of August-September. The protesters' main demand was expeditious detection and deportation of illegal infiltrators from Assam. On 15 September 2012, at a convention of non-political tribal groups, organisations representing Bodo, Dimasa, Tiwa, Deuri, Karbi, Garo, Rabha, Sonowal, Kacharis and other tribal communities decided to form a coordination committee for the cause. The tribal leaders said that illegal immigration has threatened the existence, right to land and resources to all indigenous people of the entire state, and it was not limited to Bodoland alone. (Wikipedia)

The violence in 2012 followed ethnic tensions between the indigenous Bodo people and Bengalispeaking Muslims. While the Muslim community state that they are descendants of East Bengali Muslims brought to Assam during the British Raj, local communities allege that the Muslim population has increased, boosted by refugees from the erstwhile East Pakistan prior to the Indo-Pakistani War of 1971 and by subsequent illegal migrants from Bangladesh.

By the mid-1970s, increased competition for livelihood, land and political power led to frequent incidents of violence, including the Nellie massacre after the controversial 1983 state elections, which left nearly 3,000 dead, and other large scale clashes. These incidents resulted in resentment directed at India's central government, not only from Bodos, Rabhas, Tiwas, and other indigenous tribes-people for failing to prevent illegal migration, but also from the indigenous Assamese Muslim community for failing to protect the rights of minorities.

In 1998, Srinivas Kumar Sinha, who then was governor of Assam, had sent a report to then Indian President, KR Narayanan, explaining about the problems that the unchecked illegal immigration of Bangladeshis would bring to the integrity of India. In that report, he had highlighted the history that Assam was first claimed by Pakistan during 1947 and then by Bangladesh, due to its rich natural resources. The report raised worries about what might happen if the illegal immigrants gain majority and ask for secession from India. He also cited the "Greater Bangladesh project" which might entice the immigrants to merge those regions of Assam with Bangladesh.

"The rapid growth of international Islamic fundamentalism may provide the driving force for this demand. The loss of lower Assam will severe the entire North-East from the rest of India and the rich natural resources of that region will be lost to the nation." - Srinivas Kumar Sinha

(Source: http://www.rediff.com/news/1999/feb/13secu.htm)

Ethnic tensions between Bodos and Bengali-speaking Muslims escalated into a riot in Kokrajhar on 20 July 2012, when unidentified miscreants killed four Bodo youths at Joypur. This was followed by retaliatory 
attacks on local Muslims killing two and injuring several of them on the morning of 21 July 2012. (Source: Wikipedia)

\section{Social Media And The North-East Violence}

It began in mid-July. First came a series of retaliatory killings between ethnic communities in the state of Assam in mid-July. Soon nearly 500,000 people had fled their homes for grim refugee camps. The central government belatedly sent in troops to assist, although that has barely quieted matters. But in the meantime, the violence in remote Assam triggered a bizarre series of knock-on events that has affected the entire country.

Nearly 80 people have been killed and 400,000 displaced in fighting between Muslims and mostly Hindu Bodo tribesmen in north-eastern Assam state. The mass flight was sparked by rumours that Muslims, a big minority in predominantly Hindu India, were seeking revenge for the Assam violence.

First a Mumbai demonstration in support of Muslims in Assam turned violent, leaving two people dead. Then tens of thousands of people from the northeast who lived and worked in big cities in the south of India packed up and fled back home - terrorized by Facebook, Twitter and text messages threatening them with violence in "retaliation" for what was happening in the north. The Indian government accused Pakistani agents of producing the threatening material to destabilize India. Then India went on a web crackdown, ostensibly trying to shut off the social media causing the panic - but setting off a fierce debate about censorship in the process.

\section{VIOLENCE IN THE NORTHEAST}

The seven states in the Indian northeast are connected to the rest of the country by only a tiny strip of land and often seem to exist in a whole other country. Several states have ongoing ethnic conflicts, and are covered by a law giving the Indian armed forces central powers, sharply criticized by human rights organizations. But the rest of the country knows little and, it often seems, cares less about these disputes.

So it was, initially, with the violence in Assam: in mid-July, killings began in the west of the state that has seen historic conflict between people in the Bodo ethnic group, which makes up about 35 per cent of the state population, and Bengali-speaking Muslims who migrated to the region, in some cases generations ago, from farther south - they are about 29 per cent of people in the state.

The fight, said Sanjoy Hazarika, who directs the Centre for North East Studies at Jamia Millia University in Delhi, is over access to resources, and land. Simply put, the Bodo, who hold political power in the state, won't share the resources they receive from New Delhi, which angers other groups, while the Bodo, who fear their status as the dominant group is ebbing, are desperate to hold on to power. Over the course of two weeks, some 79 people were killed, often gruesomely; at least 14,000 homes were burnt and people from both sides of the fight fled to refugee camps in one of the largest movements of people in the region since partition in 1947.

Mr. Hazarika noted that the dispute had existed as warm embers to a long-running demand for a separate Bodo state: "When governments don't get at the core of issues and when [they] leave things half-baked and unresolved these things fester." Some 190,000 people were still living in camps left over from riots in the 1990 s, he said. "Governments come and go and are incapable of sending people home in safety."

Right-wing Hindu organizations in the country including the Bharatiya Janata Party (BJP), the official opposition, blamed the trouble on illegal immigrants from Bangladesh. Mr. Hazarika rejected the idea. "Of course there are Bangladeshis coming in but nothing on the scale they are propagating - it's a mantra to divert attention from the real core issues of natural resources, political power and just economic distribution of central funds." Because the central government has failed to respond except by sending troops, he added, there is real danger these sporadic clashes could become a wider armed conflict.

\section{REPERCUSSIONS IN OTHER STATES}

The first sign that this episode of violence in the northeast was going to have an impact outside the region came when a demonstration in Mumbai on Aug. 11, organized in support of Muslim victims of alleged atrocities, became violent. Two people were killed and at least 14 were seriously injured. Some protesters said they had been shown images taken from the Internet of Muslim victims in the northeast, which inflamed the crowd.

Days later, the exodus began: thousands of people of north-eastern origin who had migrated for work to the more prosperous big cities of the south, such as Bangalore and Pune, suddenly began to flood into train stations, desperate to flee. They said they had received text messages warning them to go or face violent reprisal for what had been done to Muslims in Assam. But it wasn't just Assamese who were fleeing: people from Manipur and the other five states went too, because Indians from the rest of the country rarely distinguish between the northeast states and they all felt afraid. 
In vain, the Prime Minister and other major political figures pleaded with them to stay put and stay in their jobs. Nitin Pai, an expert on social media with a think tank called the Takshashila Institution, said it was the first time India saw what it means to be what he calls a "radically networked" country - more than threequarters of Indians have cellphones and can receive text messages. Far fewer have Internet access - but one person who sees a Facebook page or Twitter post can quickly text 50 others, he noted. "When people are connected in such a fashion it's very easy to mobilize them quickly, and mobilization is much faster than counter-mobilization. In Bangalore, by the time people in authority came to know there was a rumour and people were packing their bags, they were too late - by then 5,000 people were at the train station." The government response needed to go up a hierarchy and across ministries - and meanwhile the text messages were flying.

It was also, said Mr. Pai, indicative of how little faith people had in government's ability to protect them, and, Mr. Hazarika said, illustrated the deep distrust people from the northeast have for the central government

\section{INTERNET CRACKDOWN}

As the government began to dig in to the cause of the panic, the story became increasingly bizarre. Almost none of the images that were ostensibly outraging Muslims in the rest of India, and potentially spurring them to acts of vicious revenge, were actually of Assam. The much-circulated Facebook images were Photoshopped (often badly) pictures of atrocities allegedly carried out against Muslims in Burma several years ago or entirely unrelated pictures (such as those of Buddhist monks helping earthquake victims in Tibet) purporting to be from Assam. But the media consumers in question were not sophisticated, Mr. Pai noted, and the irrationality was lost in the mass panic.

On Aug. 19, Indian Home Minister Sushil Kumar Shinde said that government intelligence agencies had determined that the posts were originating in Pakistan, and that he had asked his Pakistani counterparts to track down and stop those responsible. Pakistan denied responsibility. Relations between the two countries, which had been thawing perceptibly, suddenly became chilly once more.

To try to stanch the exodus to the northeast, the Indian government first banned the sending of bulk text messages and then began to try to block Internet sites that hosted offensive material. But this undertaking fast became fraught: for the past three years the Indian government has battled in court with big Internet companies, such as Facebook and Google, and its own citizens over efforts at censorship. The government has been engaged in a prolonged skirmish with the companies to try to force them to screen and remove "objectionable" material.

But up until now, that material has been satirical Twitter handles and Facebook groups that mock senior members of government or the ruling Indian National Congress. "Now for a change, the government has legitimate grounds to censor speech," said Sunil Abraham, director of the Centre for Internet and Society in Bangalore, "but they've cried wolf on so many occasions before."

Nevertheless, the companies concerned have engaged the government on the issue, acknowledged that the material in question is causing harm and disrupting public order, and appear to be co-operating in its removal. The government has listed 310 items - Twitter feeds, Facebook pages, URLs - for blocking. But, Mr. Abraham noted, instead of doing that directly with the firms, it is using the much slower and more erratic approach of relying on Internet Service Providers or ISPs to do it.

Mr. Abraham said he fears what may come next: that government will see this incident as reason - or use it as a pretext - to attempt to get an even tighter hold over the Internet. "Then we're headed for big trouble." (Source: www.theglobeandmail.com)

\section{CYBER CRIME}

India is to widen the scope of its cyber-security coordinator in the wake of incendiary internet data that swept the country in August 2012 and forced an exodus of northeastern people from Pune and Bangalore.

Cyber security agencies have apparently detected the hand of radical groups, such as the Popular Front of India (PFI) in Kerala and Bangladesh-based Harkat-ul-Jehad al Islami (HuJI), while tracking SMSs that led to the exodus of Northeast people. They have been tracking SMSes — not all troublesome - from all sources. Of them, more than 60 million were sent on August 13 alone. Cyber experts say it would be difficult to trace the route of these provocative text messages because hackers normally use third-party servers. They also bounce the SMSs through several countries to avoid detection. But they have been successful in detecting forwarding of bulk messages going viral from Bangladesh groups and PFI activists. Some of the messages hold out communal threats of retribution for alleged atrocities on Rohingya Muslims in Myanmar, a community in the Arakan state linked with Bangladesh, traditionally backed by Islamist and jihadist groups, such as the HuJI.

The agencies, monitoring Facebook and Twitter, are also examining the possible role of the Hindu radical groups and the underworld. The PFI, under focus with the HuJI, is largely a Kerala-based outfit, and had a role in chopping off the hand of a professor for alleged blasphemy in 2010. It was formed on December 9, 
2006, after merging the Karnataka Forum of Dignity and Tamil Nadu-based Manitha Neethi Pasarai. In February 2009, the Citizen's Forum (Goa), Community Social and Education Society (Rajasthan), Nagrik Adhikar Surakasha Samiti (West Bengal), Lilong Social Forum (Manipur) and Andhra Pradesh-based Association of Social Justice were taken into its fold. Inheriting the operational core of the banned Students Islamic Movement of India, the PFI has a cadre of 80,000 radicals, spread over Kerala, Karnataka, Tamil Nadu, Andhra Pradesh, Rajasthan, Uttar Pradesh West Bengal and Manipur.

Even though home secretary Raj Singh has largely put the blame on Pakistan, experts are equally convinced of internal sabotage and are trying to find out who gained from the exodus. (Source: Hindustan Times)

Mr. Singh said was that some Pakistanis were involved. But investigations show that 28-30 percent of the uploads were done from Pakistan. But the question is where did the balance $70 \%$ come from?

\section{SUGGESTIONS}

"The use of bulk SMSs and social media to aggravate the communal situation is a new challenge that the recent disturbances have thrown before us... we need to devise strategies to counter the propaganda that is carried out by these new means. Any measure to control the use of such media must be carefully weighed against the need for the freedom to express and communicate," Prime Minister of India Dr. Manmohan Singh, told the State Police and intelligence chiefs and heads of paramilitary forces. "Advance identification of potential troublemakers, timely use of preventive sections of the law, alongside seeking cooperation of the community for maintaining peace, should be the first instruments to be deployed, well before the situation deteriorates. It is particularly important to obtain assistance of saner elements of the society to marginalise those who are overtly intolerant and aggressive," he added. Referring to the increase in communal incidents in the past few months and revival of ethnic tensions in the north-east, Dr. Singh said: "The ethnic disturbances of the north-east assumed a national dimension with the flight of people belonging to the north-east from various towns of south and western India. This further strained the communal situation in the country, which was already showing some signs of deterioration, particularly in the states of Uttar Pradesh, Madhya Pradesh, Maharashtra, Karnataka and Kerala." Referring to the problems of Left-wing extremism, Dr. Singh said Maoists were gradually increasing their numbers and enhancing their "military potential." He asked the Left-wing extremism-affected States to improve their police-population ratio, strengthen police infrastructure and equip the forces with better weapons. Stressing the need for pre-empting terror strikes, he said: "Realignment of operational approaches, training of police personnel and more effective collaboration among States and between States and the Centre should form part of our overall strategy of dealing with the menace of terrorism." Asking police officers to dedicate themselves to planned technological upgrading of their forces, the Prime Minister said India's vulnerability to cyber crime was escalating as economy and critical infrastructure became increasingly reliant on interdependent computer networks and the Internet. "Large-scale computer attacks on our critical infrastructure and economy can have potentially devastating results. The government is working on a robust cyber security structure that addresses threat management and mitigation, assurance and certification, specially building capacity and enhancing research," he added. (Source: The Hindu 9, Sept, 2012)

Some other suggestions are:

1. We are dealing with a domain where there are no boundaries. So it is important that there are international rules that help us curb such social media menace.

2. Proactive action by internet service providers could have cut short the number of rumors that caused the exodus from Bangalore of people from the northeast.

3. While sites such as Facebook and Twitter have now decided to block web pages containing any content that could incite violence, it raises the crucial point that this step could have been carried out before the wave of panic took over the city.

4. According to the "IT Rules 2011" under the Information Technology Act (ITA), 2000, internet companies are required to remove any content within 36 hours if the companies have been informed by the authorities that the content is considered objectionable, harmful or defamatory in any manner. The companies could also terminate access to users. The accused involved in the transmission of such messages can be punished under Section 66 (A) of the Information Technology Act (2000). According to Section 66 (A) under sub-clause (b), "Any person who sends, by means of a computer resource or a communication device, any information which he knows to be false, but for the purpose of causing annoyance, inconvenience, danger, obstruction, insult, injury, criminal intimidation, enmity, hatred, or ill will," can be punished under the Act up to three years and with a fine of Rs. 5 lakh. But lack of proper implementation and awareness of this Act and its Rules have led to the misuse of the cyberspace.

5. A private service provider told The Hindu that the company cannot resort to blocking or screening of messages unless a police complaint is registered. It is difficult to view the content of each message that 
is transmitted. Besides, it also concerns the privacy of individuals. It is difficult to keep track of the content when there is a large consumer-base as well. Similarly, email Spoofing - when an email message appears to have originated from one source when it actually was sent from another source is usually resorted to when sensitive information has to be released. To trace the origin of such messages, full headers are required to trace the IP address. But the address is difficult to procure as it could mean a breach of confidentiality. Here, it should be understood that public interest is above Right to privacy of individuals and it should not be termed as 'breach of confidentiality'.

6. Pune cyber crime cell, that has been investigating the cases of provocative SMSs and MMSs that allegedly triggered violence against residents of North Eastern states in August 2012, has admitted that the probe has reached a dead end, with the sleuths failing in tracking down the original sender of those doctored messages. They have cited some "technical reasons" for this failure. Till date, the cell has arrested five persons in connection with the cases. Police investigation revealed that the fear was generated by inflammatory messages that were being circulated among people in days prior to exodus. The clips had used disturbing images of violence and dead bodies that reportedly had some links to riots in Myanmar. The SMSs, however, that were sent around had wrongly linked people from the Northeastern states to them due to their mongoloid features. Primary investigation had led the police to arrest four persons from Pune for sending and spreading the SMSs. A teacher from Mumbai was also arrested for having allegedly uploaded the video 'Burma Riots, Thrilling Pictures 2012' on youtube.com. In the days hat followed, many YouTube videos, Facebook accounts and Blogs were removed from public domain on Pune police's request. In this case, police investigation was mainly based on information received from social networking sites. Cases were registered under Section 153(a) of IPC for inciting negative feeling between different communities, as well as Section 66 of Information Technology Act. A senior officer with the cyber crime cell said: "We have now reached a dead end in this probe. We arrested a person who had uploaded the clip on YouTube, which was later circulated as MMS. But more than 15 such videos were uploaded from Pakistan. Though we have traced the IP (Internet Protocol) addresses, there is a very lengthy process for further action and we have no chance of a breakthrough." The officer further said, "In case of the SMSs, we have arrested people who had forwarded these SMSs in bulk. But we have not been able to find out from where these SMSs originated. We do not have the means to reach them. So in case of SMSes too, we have reached the dead end." (Source: India Express, 5, March 2013) Thus it is very important that there should be political will to support the investigative agencies and motivate them to nab the culprits anyhow. It is often seen that police and investigative agencies search for easy alternatives and tend to avoid lengthy routes. Such attitudes should be done away with if we really want to instil security in the minds of our citizens.

7. It is indeed a sad state of affairs that even after almost two years have passed since the incident took place, yet our government is showing reluctance is making stringent cyber laws that would be exemplary and help curb cyber crimes in the nation.

\section{Conclusion}

An The August 2012 exodus of people from the Northeast from cities like Bengaluru, Mumbai, Pune and Chennai added another alarming dimension to cyber crimes. Started as a 'rumour' that was propagated via social networking sites and SMSs, it lead to widespread panic that made thousands of people of Northeast origin to flee to their home towns. Even as fingers were pointed at Pakistan, latest media reports suggest that most of the hate content on the websites that was attributed to Pakistan was focussed only on Myanmar.

Unlike China which targets important defence networks, Pakistan usually attempts to hack into Indian websites mainly to 'spread hatred'. Many hacker groups on the Internet such as 'armyinkashmir', 'Pakistan G Force', 'Pakistan Cyber Army', 'Pakistan Hackers Club' so on and so forth targeted nearly 500 Indian websites including those of BSNL and CBI to access personal information like email ids, phone numbers, etc. Tactical cyber attacks could be used to manipulate the flow of information to shape public opinion.

The government's lack of understanding of the subject is also giving the necessary advantage to such hacker groups. In the recent report, 'India Risk Survey 2012', Federation of Indian Chambers of Commerce and Industry (FICCI) had listed 'Information and Cyber Insecurity' as a top risk to the government and business establishments alike. "While IT and financial sectors count cyber insecurity as their apex risk, even government, manufacturing and telecom sectors have rated it as their top three risks," the report stated. Adding on the existing risks in the cyber space, social networking sites provided the perfect platform to launch rumours, especially to create unrest in sensitive areas like the Northeast and Jammu \& Kashmir.

It might sound stranger than fiction but the story lies in the sequence of events that happened, starting with the clashes in Assam and the versions that played out on the social networking sites. The violence started between the Bodos and the immigrant Muslim community in the Kokhrajar district of Assam in July 2012. It 
subsequently spread to the adjoining districts taking the death toll to nearly 80 and lakhs of people living in more than 200 relief camps. This was probably the first time that the broadcast media, which otherwise is mainly focussed on Delhi-centric news, covered this event in all seriousness. The outrage on Twitter and other social networking sites closely followed. (Source: www.forceindia.net)

We'll have to work at multiple levels. We have to put in filters. But then, who owns the Internet? The whole world owns it. It's a new domain. It's a whole new ball game.

Thus, we can conclude that somewhere down the line there are other players who, through the use of social media, spread hatred and messages of disaster and fear. The exodus of August 2012 should be taken as an alarm call to wake up and act before such disaster crops up again. It is high time there should be some stringent International law in place so that anti-social elements from within different countries cannot take liberty to spread chaos in other nations with the click of the mouse or mobile phone.

\section{REFERENCES}

[1]. Barefoot, Darren \& Szabo, Julie. (2010). Friends with Benefits: A Social Media Marketing Handbook. No Starch Press Pub

[2]. Evans, Dave. (2012). Social Media Marketing: An Hour a Day. Sybex Pub.

[3]. Frakes, Linda (2010). What the Heck Is Social Media... and why Does My Business NEED IT?

[4]. http://www.forceindia.net/riotsandthecybergoons.aspx

[5]. http://blog.thoughtpick.com/2010/11/10-must-know-advantages-disadvantages-of-social-media.html

[6]. http://www.nytimes.com/2012/08/18/world/asia/panic-radiates-from-indian-state-of-assam.html?_r=0

[7]. http://phys.org/news/2012-09-indian-pm-dangers-social-media.html

[8]. http://www.theglobeandmail.com/news/world/indias-ethnic-clashes-intensify-within-social-media-maelstrom/article4496392/

[9]. http://www.thehindu.com/news/cities/bangalore/mischief-potential-of-social-media-in-full-play/article3781473.ece

[10]. http://www.thehindu.com/news/national/use-of-social-media-to-aggravate-communal-situation-a-new-challenge-saysmanmohan/article3874014.ece

[11]. http://www.hindustantimes.com/India-news/NewDelhi/Northeast-exodus-rogue-SMSes-traced-to-HuJI-Kerala-group/Article1916814.aspx

[12]. http://en.wikipedia.org/wiki/2012_Assam_violence

[13]. http://archive.indianexpress.com/news/cyber-cell-admits-to-failure-in-ne-violence-exodus-case/1083180/0 